Methodology article

\title{
Coupling amplified DNA from flow-sorted chromosomes to high-density SNP mapping in barley
}

\author{
Hana Šimková1,2, Jan T Svensson ${ }^{3,4}$, Pascal Condamine ${ }^{3}$, Eva Hřibová1, \\ Pavla Suchánková1, Prasanna R Bhat ${ }^{3}$, Jan Bartoš ${ }^{1}$, Jan Šafár ${ }^{1}$, \\ Timothy J Close ${ }^{3}$ and Jaroslav Doležel ${ }^{* 1,2}$
}

\begin{abstract}
Address: ${ }^{1}$ Laboratory of Molecular Cytogenetics and Cytometry, Institute of Experimental Botany, Sokolovská 6, CZ-77200 Olomouc, Czech Republic, ${ }^{2}$ Department of Cell Biology and Genetics, Palacký University, Šlechtitelů 11, CZ-78371 Olomouc, Czech Republic, ${ }^{3}$ Department of Botany and Plant Sciences, University of California, Riverside, CA-92521-0124, USA and ${ }^{4}$ VKR Center of Excellence Pro-Active Plants, Department of Plant Biology and Biotechnology, University of Copenhagen, DK-1871 Frederiksberg C, Denmark

Email: Hana Šimková - simkovah@ueb.cas.cz; Jan T Svensson - jsv@life.ku.dk; Pascal Condamine - pascalcondamine@yahoo.fr; Eva Hřibová - hribova@ueb.cas.cz; Pavla Suchánková - suchankova@ueb.cas.cz; Prasanna R Bhat - prasanna.bhat@ucr.edu; Jan Bartoš - bartos@ueb.cas.cz; Jan Šafář - safar@ueb.cas.cz; Timothy J Close - timothy.close@ucr.edu; Jaroslav Doležel* - dolezel@ueb.cas.cz

* Corresponding author
\end{abstract}

Published: 19 June 2008

BMC Genomics 2008, 9:294 doi:10.1/86//47|-2164-9-294
Received: 16 April 2008

Accepted: 19 June 2008

This article is available from: http://www.biomedcentral.com/I47I-2/64/9/294

(c) 2008 Šimková et al; licensee BioMed Central Ltd.

This is an Open Access article distributed under the terms of the Creative Commons Attribution License (http://creativecommons.org/licenses/by/2.0), which permits unrestricted use, distribution, and reproduction in any medium, provided the original work is properly cited.

\begin{abstract}
Background: Flow cytometry facilitates sorting of single chromosomes and chromosome arms which can be used for targeted genome analysis. However, the recovery of microgram amounts of DNA needed for some assays requires sorting of millions of chromosomes which is laborious and time consuming. Yet, many genomic applications such as development of genetic maps or physical mapping do not require large DNA fragments. In such cases time-consuming de novo sorting can be minimized by utilizing whole-genome amplification.

Results: Here we report a protocol optimized in barley including amplification of DNA from only ten thousand chromosomes, which can be isolated in less than one hour. Flow-sorted chromosomes were treated with proteinase $\mathrm{K}$ and amplified using Phi29 multiple displacement amplification (MDA). Overnight amplification in a 20-microlitre reaction produced $3.7-5.7$ micrograms DNA with a majority of products between 5 and $30 \mathrm{~kb}$. To determine the purity of sorted fractions and potential amplification bias we used quantitative PCR for specific genes on each chromosome. To extend the analysis to a whole genome level we performed an oligonucleotide pool assay (OPA) for interrogation of I524 loci, of which II 53 loci had known genetic map positions. Analysis of unamplified genomic DNA of barley cv. Akcent using this OPA resulted in 1426 markers with present calls. Comparison with three replicates of amplified genomic DNA revealed $>99 \%$ concordance. DNA samples from amplified chromosome $\mathrm{IH}$ and a fraction containing chromosomes $2 \mathrm{H}-7 \mathrm{H}$ were examined. In addition to loci with known map positions, 349 loci with unknown map positions were included. Based on this analysis 40 new loci were mapped to $\mathrm{IH}$.

Conclusion: The results indicate a significant potential of using this approach for physical mapping. Moreover, the study showed that multiple displacement amplification of flow-sorted chromosomes is highly efficient and representative which considerably expands the potential of chromosome flow sorting in plant genomics.
\end{abstract}




\section{Background}

Advances in sequencing technologies facilitate rapid progress in understanding plant genome structure, function and evolution. However, the majority of sequencing efforts have targeted plant species with relatively small genomes, typically less than $700 \mathrm{Mbp}$ (for example see [1]). But many plants and important crops, including major cereals such as barley, wheat and rye have genomes that are many time larger [2]. Different strategies have been proposed to tackle these genomes, including reduced-representation sequencing (reviewed by [3]) or the use of ancestral or taxonomically closely related species with smaller genomes $[4,5]$.

We have been pursuing another strategy that is based on our ability to prepare suspensions of intact mitotic chromosomes and to sort individual chromosomes and chromosome arms using flow cytometry [6]. Genome analysis can be simplified by dissecting a large genome into these smaller parts, in some species representing only a few percent of the whole genome, as is the case of wheat $[7,8]$. Chromosome sorting has been reported in at least seventeen plant species, including major legumes and cereals [6]. Flow-sorted chromosomes have been used in variety of studies, including targeted development of markers for specific genome regions [9-11], physical mapping of DNA sequences using PCR $[12,13]$ and localization of DNA sequences to chromosomes using FISH and PRINS [1416]. The most attractive application has been the construction of chromosome- and chromosome arm-specific BAC libraries [17-19]. Their availability greatly facilitates development of physical contig maps [20] and positional gene cloning [21] in species with complex genomes.

The construction of BAC libraries requires microgram amounts of high molecular weight DNA. In order to obtain this amount of large DNA fragments, millions of chromosomes must be sorted which is laborious and time consuming [17]. However, many methods, for example those which utilize PCR to create small amplicons are not constrained by a requirement for large template molecules and can in principle be supported using DNA amplified from sorted chromosomes. Thus, a practical approach to the production of sufficient amounts of moderate-size DNA from particular chromosomes is to sort a more modest number of chromosomes and then amplify their DNA. There are several methods for non-specific DNA amplification, most of them being based on PCR. However, these methods such as DOP-PCR (degenerate oligonucleotide primed PCR) [22] or PEP (primer extension preamplification) [23] are characterized by high amplification bias and provide incomplete genome coverage [24,25]. Moreover, they generate DNA fragments less than $3 \mathrm{~kb}$ long, which may be not suitable for some applications.
Recently, a protocol for isothermal multiple displacement amplification (MDA) was developed, which uses the Phi29 polymerase and random primers to amplify the whole genome $[24,26]$. The protocol has been shown suitable for many applications such as RFLP analysis, chromosome painting [24], comparative genome hybridization [24,27] and SNP genotyping [28-32]. Data obtained from these prior studies indicated that the genome representation achieved after MDA is comprehensive. For example, Paez et al. [30] using high-density oligonucleotide arrays estimated the genome representation to be $99.82 \%$ complete. Similarly, Barker et al. [29] observed a concordance of $99.8 \%$ in SNP genotyping from genomic DNA and MDA-amplified human DNA, and they achieved a SNP call rate of $98 \%$ in both genomic and amplified DNA. Pinard et al. [25] compared two multiple displacement amplification methods, GenomiPhi (GE Healthcare, Chalfont St. Giles, United Kingdom) and Repli-G (Qiagen Sciences Inc., Germantown, USA). In his sequencing-based study, Repli-G generated more amplified DNA, but introduced marginally more bias than GenomiPhi, and generated significantly lower genome coverage, indicating the GenomiPhi the best available system for whole genome amplification.

In this work we have optimized for the first time a protocol for amplification of DNA from flow-sorted plant chromosomes by MDA using barley as our model system. Here we report excellent coverage of amplification, confirmed on a whole genome level using an oligonucleotide pool assay.

\section{Methods \\ Preparation of chromosome suspensions and flow- cytometric sorting}

Mitotic metaphase chromosomes of barley (Hordeum vulgare $\mathrm{L} ., 2 \mathrm{n}=2 \mathrm{x}=14) \mathrm{cv}$. Akcent were flow-sorted according to Lysák et al. [33]. Briefly, barley seedlings were treated subsequently with hydroxyurea and amiprophosmethyl to accumulate meristem root tip cells at metaphase and the synchronized root meristems were fixed by formaldehyde. Chromosome suspensions were prepared by mechanical homogenization of 25 root tips in 1 $\mathrm{ml}$ ice-cold LB01 buffer [34] and stained by $2 \mu \mathrm{g} / \mathrm{ml}$ DAPI (4',6-diamidino-2-phenylindole). The stained samples were analyzed using a FACSVantage SE flow cytometer and sorter (Becton Dickinson, San José, USA). Batches of 10,000 chromosomes $1 \mathrm{H}$ and of 60,000 chromosomes $2 \mathrm{H}-7 \mathrm{H}$ were sorted into $50 \mu \mathrm{l}$ deionized water in a PCR tube. Purity in sorted fractions was checked regularly by FISH using a probe for GAA microsatellite as described in Suchánková et al. [35]. 


\section{Purification and amplification of chromosomal DNA}

Flow-sorted chromosomes were treated with proteinase $\mathrm{K}$ at $50^{\circ} \mathrm{C}$ for 36 hours in a buffer consisting of $2.5 \mathrm{mM}$ Tris (pH 8.0), $1.25 \mathrm{mM}$ EDTA ( $\mathrm{pH} 8.0)$ and $0.125 \%(\mathrm{w} / \mathrm{v})$ SDS. Freshly prepared proteinase K $(0.5 \mathrm{mg} / \mathrm{ml})$ was added in a volume of $4 \mu \mathrm{l}$ to the 10,000-chromosome samples and $8 \mu \mathrm{l}$ to the 60,000-chromosome samples. Another 2 or $4 \mu \mathrm{l}$ (half of the original amount) were added after 20 hours of the treatment. The proteinase $\mathrm{K}$ was then removed and the buffer was exchanged using Microcon YM-100 column (Millipore Corporation, Bedford, USA) in four rounds of centrifugation at $500 \mathrm{~g}$ for 15 $\min$ at $23^{\circ} \mathrm{C}$. About $450 \mu$ d deionized water were added to the column before each centrifugation to wash out the buffer. After purification, the amount of DNA in the samples was estimated using TD-700 fluorometer (Turner Designs, Sunnyvale, USA). As the volume after purification was usually 10-20 $\mu \mathrm{l}$, it was reduced by overnight evaporation at $4^{\circ} \mathrm{C}$ to reach volume of $1-2 \mu$ l. The amplification of purified chromosomal DNA was performed using GenomiPhi DNA Amplification Kit (GE Healthcare, Chalfont St. Giles, United Kingdom) according to instructions of the manufacturer in a $20 \mu \mathrm{l}$ reaction for 16 hours. The samples were lyophilized for storage and shipment. For further processing, samples were resuspended in 100 $\mu \mathrm{l}$ of $10 \mathrm{mM}$ Tris-HCl, $0.1 \mathrm{mM}$ EDTA ( $\mathrm{pH}$ 8.0) of which $50 \mu$ were de-salted on MicroSpin G50 columns (GE Healthcare). Concentrations were measured by absorbance at $260 \mathrm{~nm}$ and using the Quant-iT PicoGreen assay (Invitrogen, Carlsbad, USA).

\section{Analysis of the amplification products by Southern hybridization}

Southern hybridization with barley genomic DNA as a probe was used to analyze composition of the amplification product. The probe was labeled using AlkPhos Direct kit (GE Healthcare). In the first experiment, $5 \mu \mathrm{g}$ of the multiple-displacement-amplified barley chromosomes $(1 \mathrm{H}-7 \mathrm{H})$ were run in a $1.5 \%$ agarose gel in $0.5 \times \mathrm{TBE}$ and subsequently transferred onto a nylon membrane (Hybond N+, GE Healthcare) by alkali transfer. Hybridi- zation ran overnight at $55^{\circ} \mathrm{C}$, followed by standard posthybridization washes. Visualization of the hybridization product was performed by membrane incubation with a chemiluminiscent substrate (CDP Star, GE Healthcare) followed by 4 hours exposure to X-ray film. To quantify the portion of barley-derived DNA in the amplification product, dot blot analysis was performed. Serial dilutions of $40,20,10,5,2,1$ and $0.5 \mathrm{ng}$, respectively, were spotted on a nylon membrane for both barley amplified and unamplified DNA. Hybridization and signal detection were performed as above.

\section{Real-time quantitative PCR}

Real-time quantitative PCR was used to check the purity of the sorted fractions and potential amplification bias of the MDA. Primers were designed for four genes localized on chromosome $1 \mathrm{H}$, and one gene for each of the remaining chromosomes (Table 1). Primer design was done using Primer Express (Applied Biosystems, Foster City, USA). The PCRs were performed in 96-well plates. A standard curve was constructed for each amplicon with serial dilutions of genomic DNA $(30,15,7.5,3.75,1.875,0.9375$, $0.46875 \mathrm{ng} /$ well). Standards and samples were run in duplicate. Each $25 \mu \mathrm{l}$ reaction consisted of $12.5 \mu \mathrm{l}$ of SYBR Green PCR Master Mix (Applied Biosystems), $1 \mu \mathrm{l}$ of each primer $(10 \mu \mathrm{M})$ and $1.5 \mu \mathrm{l}$ of DNA (3 ng for the samples and between 30 and $0.46 \mathrm{ng}$ for the standards). The realtime PCR analysis was performed on an Applied Biosystems Prism 7700 Sequence Detection System (Applied Biosystems). Thermocycling was as follows: $50^{\circ} \mathrm{C}$ for 2 min and $95^{\circ} \mathrm{C}$ for $10 \mathrm{~min}$ followed by 40 cycles of $95^{\circ} \mathrm{C}$ for $15 \mathrm{~s}$ and $60^{\circ} \mathrm{C}$ for $1 \mathrm{~min}$.

\section{Assessment of amplified genomic DNA using an oligonucleotide pool assay}

Genetic marker analysis was done using an Illumina GoldenGate BeadArray (Illumina, San Diego, USA) with an Oligo Pool Assay (OPA) for interrogation of 1524 barley markers [36]. Processing of DNA was done by Joe DeYoung and staff at the Southern California Genotyping Consortium at University of California, Los Angeles, fol-

Table I: Primers for real-time quantitative PCR

\begin{tabular}{lllll}
\hline Chr. & Gene & Forward $\left(\mathbf{5}^{\prime} \mathbf{-} \mathbf{3}\right.$ ') & Reverse (5' - 3') & Amplicon (bp) \\
\hline IH & HemA2 & CACGCCATCTGTTTGAGGTATC & TCTTTCCCAGGCCTCCACTAT & 120 \\
IH & Hor3 & TGTGTTGGCAAACTGCACTTG & TTGTGAGGCCCTTAAGTCGG & 123 \\
IH & Hval & CTCCACAAGCAGTCGATCCA & GGCCATCTTCGTCTCACGAT & III \\
IH & Nbs & CAACCTACACCGGAAACTCATCT & TTGTGAGGCCCTTAAGTCGG & 137 \\
2H & Corl $4 b$ & CCCAAACAGGTCACCCAAAG & TGCGTGCGAGACTGTCGAC & 139 \\
3H & Dhnl0 & GGGTTCTCGATCTCTTCTTGCAT & TCTTCCTCCGTCCACCCA & 177 \\
4H & Dhn6 & GGACGTACGGCGCTACTGAG & TGGTTCCTCGAGTCTTTATTCTTCA & 150 \\
5H & Dhn9 & GTTCCACGTGATCTTCATTCAATAA & TCAGCAAGAAGACACAAGAACACA & 137 \\
6H & Dhn8 & CCGTCCTTCTTTCTTGCTTGTG & TATAGCCGCTGTCAAGTAGACCG & 100 \\
7H & Ssl & CTTGGCCGGGATGCGTTA & GGTGTGGGTATCCGAGGGAG & 101
\end{tabular}




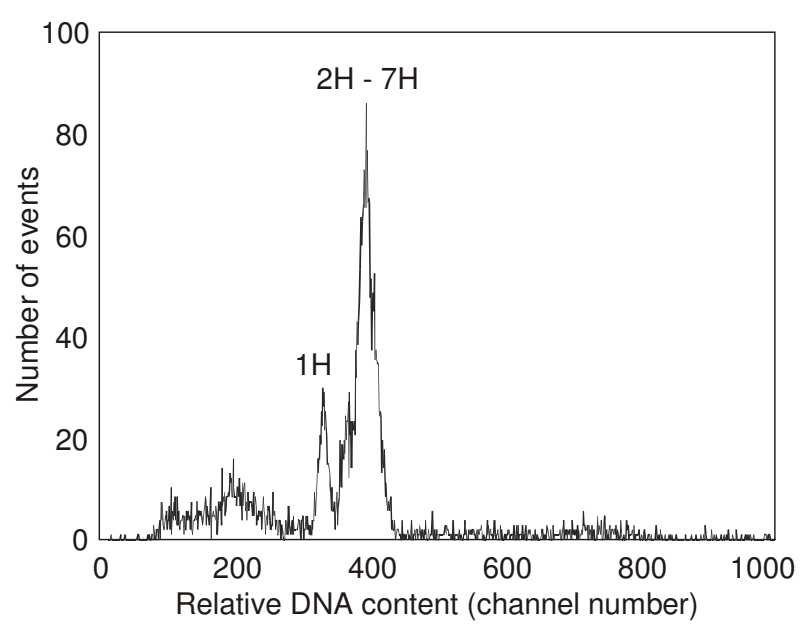

Figure I

Flow karyotype of barley. Histogram of relative DNA contents (flow karyotype) obtained after flow cytometric analysis of DAPI-stained liquid suspension of intact mitotic chromosomes of barley. The peak of chromosome $\mathrm{IH}$ is clearly resolved, which enables isolation of $\mathrm{IH}$ by flow sorting.

lowing standard procedures. Marker data were supervised manually using the GenCall software (Illumina). In order to compare the performance of amplified to unamplified genomic DNA, marker analysis included both amplified and unamplified DNA of cv. Akcent, together with unamplified DNA from 102 barley accessions [36]. Marker calls of Akcent were accepted if an Akcent datum clustered with marker data from the germplasm collection. Markers with low GenCall scores were tagged as "no call" and not considered further. To add certainty, three replicates of amplified Akcent DNA were used. The GenCall software's calling function was used to produce genotype allele calls (AA, AB, BB) and the GenCall score. Allele calls from the replicated samples of amplified Akcent and the unamplified sample of Akcent were analyzed for concordance and the reproducibility was evaluated by calculating the coefficient of variation (CV, standard deviation as a percentage of the mean). Only markers with a high concordance and reproducibility were further considered.

\section{Marker analysis of amplified flow-sorted chromosomes using the OPA}

We also analyzed DNA amplified from sorted chromosome $1 \mathrm{H}$ and from a pool of sorted chromosomes $2 \mathrm{H}-$ $7 \mathrm{H}$. We calculated the ratio of GenCall values from $1 \mathrm{H}$ and $2 \mathrm{H}-7 \mathrm{H}$ for each locus and examined the distribution of these ratios in the context of previously mapped markers to heuristically define $1 \mathrm{H}$, uncertain or $2 \mathrm{H}-7 \mathrm{H}$ bins.

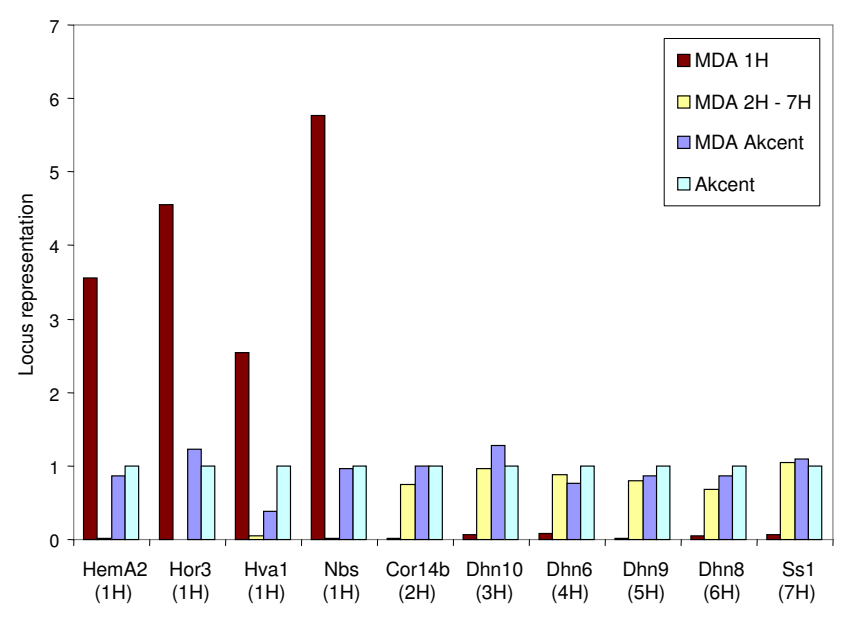

Figure 2

Locus representation in amplified DNA relative to unamplified DNA. Four IH-specific loci and one locus from each of the remaining chromosomes were examined for representation by real-time quantitative PCR with genespecific primers. The RT PCR was run on amplified IH chromosomes (MDA IH), amplified $2 \mathrm{H}-7 \mathrm{H}$ chromosomes (MDA 2H-7H), amplified Akcent DNA (MDA Akcent) and unamplified Akcent genomic DNA (Akcent).

\section{Results and Discussion Chromosome sorting}

Histograms of relative fluorescence intensity obtained after flow-cytometric analysis of chromosomes isolated from barley cv. Akcent consisted of a small peak representing chromosome $1 \mathrm{H}$ and a composite peak representing the remaining chromosomes $2 \mathrm{H}-7 \mathrm{H}$ (Figure 1 ). This observation confirmed our previous results [33,35] and enabled sorting of chromosome $1 \mathrm{H}$. The purity in sorted $1 \mathrm{H}$ fractions as determined by FISH exceeded 95\%.

\section{Optimization of chromosome treatment for DNA amplification}

After DNA purification, 7 - 70 ng of chromosomal DNA were obtained from flow-sorted fractions (depending on the number of sorted chromosomes), which were subsequently used for multiple displacement amplification. The yield of amplified DNA varied from 3.7 to $5.7 \mu \mathrm{g}$. A critical step of the procedure was the purification of samples after proteinase treatment using the Microcon YM100 columns. If the buffer was not exchanged completely (by reducing the number of centrifugations), remnants of proteinase $\mathrm{K}$ and the buffer interacted with Phi29 polymerase and hampered the amplification. On the other hand, additional rounds of centrifugation and especially spinning to dryness drastically reduced the recovery of chromosomal DNA (to approximately $1 \mathrm{ng}$ ). While this did not significantly influence the amount of amplifica- 

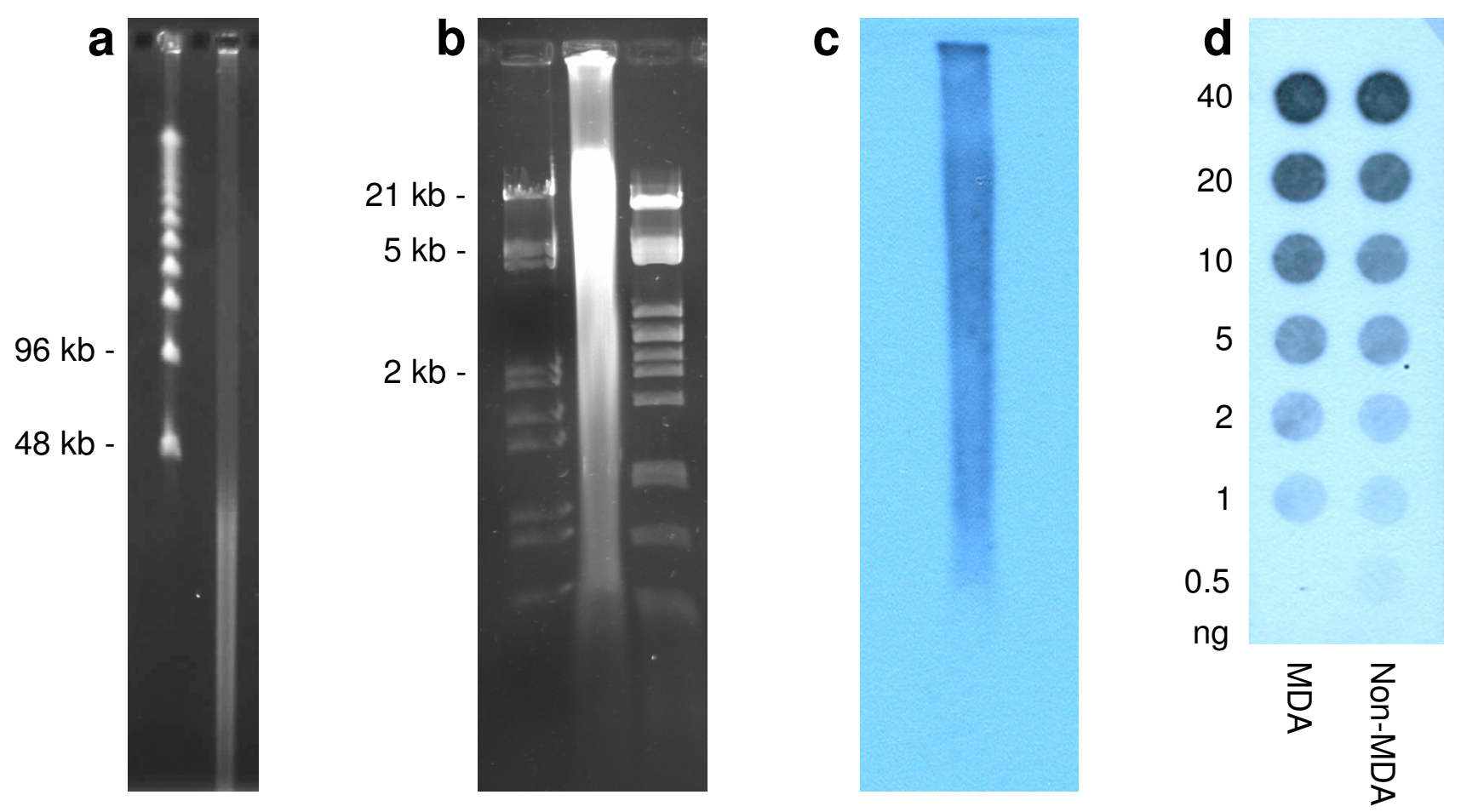

\section{Figure 3}

Analysis of the product of multiple displacement amplification on flow-sorted chromosomes. (a) $500 \mathrm{ng}$ of the product were analyzed by pulsed field gel electrophoresis in $1 \%$ agarose gel, $0.25 \times \mathrm{TBE}$ at $12.5^{\circ} \mathrm{C}, 6 \mathrm{~V} / \mathrm{cm}$ and $5-15 \mathrm{~s} \mathrm{switch}$ time ramp for 15 hours. Lambda ladder was used as a size standard. (b) $5 \mu \mathrm{g}$ of the product were analyzed in I.5\% agarose gel in $0.5 \times$ TBE and (c) after transfer on nylon membrane hybridized with barley genomic DNA. (d) Dot blot of barley genomic DNA (Non-MDA) and amplified DNA of all barley chromosomes (MDA) hybridized with barley genomic DNA.

tion product, it decreased the representation of some loci in the amplification product as demonstrated by real-time PCR (data not shown). Amplification bias inversely correlating with the amount of template was observed also by Rook et al. [37] and Bergen et al. [38]. These data are in agreement with the manufacturer's instructions according to which at least $1 \mathrm{ng}$ (optimum $10 \mathrm{ng}$ ) of purified DNA is to be used for the reaction to warrant minimum amplification bias.

Quantitative PCR using primers for four genes localized on chromosome $1 \mathrm{H}$ (Table 1) showed high quantities of PCR products both in the $1 \mathrm{H}$ and genomic DNA samples. Samples of amplified flow-sorted $1 \mathrm{H}$ chromosomes showed maximum 2.3-fold difference in the copy number among the 1H-specific loci (Figure 2). Several-fold higher quantities of PCR products obtained with DNA amplified from chromosome $1 \mathrm{H}$ reflect the fact that the samples of flow-sorted chromosomes were enriched seven-fold in number of loci per unit of mass as compared to genomic DNA. For genes localized on the remaining chromosomes $(2 \mathrm{H}-7 \mathrm{H})$ even lower amplification bias (1.5-fold) among the six loci was observed (Figure 2). This is a similar level of amplification bias as observed by Dean et al. [24] who compared amplification of 8 genes from blood and tissue cultured cells and observed less than a threefold bias, Hosono et al. [28] who analyzed amplification of 47 loci in DNA from clinical samples revealing maximum six-fold bias, and Rook et al. [37] who observed maximum three-fold bias when comparing amplification of 4 loci in samples of laser-capture microdissected cells. Samples of chromosomes $2 \mathrm{H}-7 \mathrm{H}$ where 60,000 purified chromosomes were used as a template provided lower amplification bias compared with those of $1 \mathrm{H}$ where only 10,000 chromosomes were used. This corresponds to similar findings of Rook et al. [37] who observed an inverse correlation between amplification bias and the amount of template. RT-PCR showed only minor contamination of the $1 \mathrm{H}$ fraction by other chromosomes (Figure 2 ).

\section{Characterization of the amplification product}

The multiple-displacement-amplified (MDA) DNA of flow-sorted chromosomes was analyzed by electrophoresis under various conditions (Figure $3 \mathrm{a}, \mathrm{b}$ ). The majority 

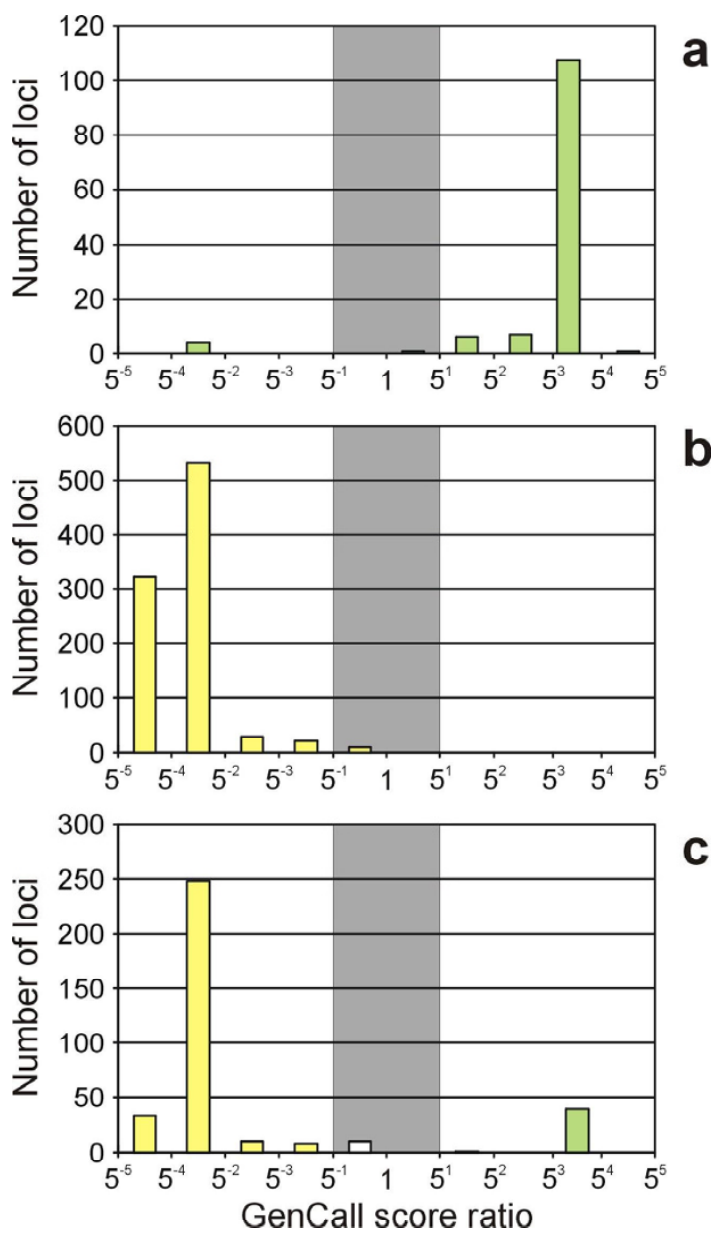

\section{Figure 4}

Histogram of the ratio of GenCall scores ( $\mathrm{IH} / 2 \mathrm{H}$ 7H). (a) 127 loci previously mapped to IH, (b) 920 loci previously mapped to $2 \mathrm{H}-7 \mathrm{H}$ and (c) mapping 349 loci with unknown map position. Loci mapped to IH (GenCall score ratio $\left.5^{\mathrm{I}}-5^{5}\right)$ are shown in green. Loci mapped to $2 \mathrm{H}-7 \mathrm{H}$ (GenCall score ratio $5^{-5}-5^{-1}$ ) are shown in yellow. Cutoff region (GenCall score ratio $5^{-1}-5$ ) is shown in grey. Note that the $X$ axis is shown in $\log _{5}$ scale.

of products were found between 5 - $30 \mathrm{~kb}$. The MDA using random hexamers to prime the DNA amplification is known to generate amplification product also in the absence of template DNA [38]. This spurious product is electrophoretically indistinguishable from that obtained in the presence of template. Therefore we analyzed the composition of the MDA product obtained with flowsorted chromosomes. Southern hybridization with barley genomic DNA used as a probe revealed that the product in its whole size spectrum was derived from barley DNA (Figure 3c). To quantify the portion of barley-derived
DNA in the MDA product we performed dot blot analysis comparing serial dilutions of barley amplified and unamplified DNA hybridized with barley genomic DNA. The hybridization showed high concordance of both samples indicating that a large percent of the amplified DNA was barley-derived rather than nonspecific synthesis (Figure 3d).

\section{Genome wide survey of amplified barley DNA}

We previously developed an OPA for interrogation of 1524 barley SNPs [36]. We observed 1426 loci with highconfidence marker calls for Akcent genomic DNA. Comparison of the allele calls for Akcent DNA samples (amplified or unamplified) revealed only one locus with different allele call for one of the amplified replicates compared to un-amplified Akcent DNA, resulting in a concordance of $99.98 \%$. Similar studies using MDA on genomic DNA from human cell lines also resulted in $>99 \%$ concordance $[29,31]$. In addition, we found high reproducibility for the three replicates of amplified Akcent DNA; the coefficient of variation (CV) of GenCall scores was below $2 \%$ for 1398 of the 1426 loci $(98.0 \%)$. This shows that the replicates of amplified Akcent DNA clustered very close together as was evident also from manual inspection of the genotyping clusters. In summary, we were able to score the marker call as plus/minus for the entire dataset by including Akcent as a reference dataset.

\section{Isolated chromosomes as a tool for physical mapping}

We also applied the OPA to amplified DNA of flow-sorted barley chromosomes $1 \mathrm{H}$ and $2 \mathrm{H}-7 \mathrm{H}$, respectively (see Materials and Methods). We classified the 1426 loci with good genotype calls from unamplified Akcent genomic DNA into four sub-sets based on their map data: (i) 130 known $1 \mathrm{H}$ loci, (ii) 920 known 2H - 7H loci, (iii) 349 loci with previously unknown map position, and (iv) 27 loci with ambiguous map positions (mapped to different chromosomes dependent on the mapping population used).

For the 130 loci previously mapped to $1 \mathrm{H}$, we expected a high GenCall $1 \mathrm{H} / 2 \mathrm{H}-7 \mathrm{H}$ score ratio (see Materials and Methods). This expectation was fulfilled for $93.8 \%$ of these markers (122 of 130) which had a ratio of at least 5.0 (Figure 4a). Interestingly, four loci were nulls in the $1 \mathrm{H}$ fraction but not in the $2 \mathrm{H}-7 \mathrm{H}$ fraction (these loci had a ratio of $0.003-0.002$ ). These anomalies have been subsequently explained as an incorrect assumption that subclustering patterns within the genotyping data represented the targeted SNP.

We conducted a parallel analysis of the 920 loci previously mapped to chromosomes $2 \mathrm{H}-7 \mathrm{H}$, of which the GenCall score ratios for $98.7 \%$ (908 of 920) were less than 0.2 (Figure $4 \mathrm{~b}$ ). One locus had a ratio of 162 , which also 
Table 2: Using sorted chromosomes IH and $2 \mathrm{H}-7 \mathrm{H}$ to determine chromosome location of ambiguously mapped loci

\begin{tabular}{|c|c|c|c|c|c|c|c|c|}
\hline Locus name & $\begin{array}{c}\text { Morex } x \\
\text { Barke }\end{array}$ & OWBs & $\begin{array}{l}\text { Steptoe } x \\
\text { Morex }\end{array}$ & $\begin{array}{l}\text { Allele call } \\
\text { Akcent }\end{array}$ & Allele call IH & $\begin{array}{c}\text { Allele call } 2 \mathrm{H}- \\
\mathbf{7 H}\end{array}$ & $\begin{array}{c}\text { Ratio of } \\
\text { GenCall } \\
\text { score }^{a}\end{array}$ & Chrom. \\
\hline I_0198 & $\mathrm{IH}$ & $\mathrm{IH}$ & $5 \mathrm{H}$ & B & B & B & 488 & $\mathrm{IH}$ \\
\hline I_0716 & $\mathrm{IH}$ & $3 \mathrm{H}$ & $3 \mathrm{H}$ & $A$ & $A$ & A & 479 & $\mathrm{IH}$ \\
\hline I_0549 & $6 \mathrm{H}$ & $\mathrm{Nd}$ & $\mathrm{IH}$ & B & B & B & 436 & $\mathrm{IH}$ \\
\hline I_0443 & $\mathrm{IH}$ & $\mathrm{Nd}$ & $5 \mathrm{H}$ & B & B & $A B$ & 435 & $\mathrm{IH}$ \\
\hline I_0644 & $\mathrm{IH}$ & $6 \mathrm{H}$ & nd & B & B & B & 412 & $\mathrm{IH}$ \\
\hline I_0075 & $\mathrm{IH}$ & $7 \mathrm{H}$ & $7 \mathrm{H}$ & $A$ & $A$ & B & 306 & $\mathrm{IH}$ \\
\hline I_1223 & $\mathrm{IH}$ & $5 \mathrm{H}$ & nd & B & B & $A B$ & 299 & $\mathrm{IH}$ \\
\hline I_0148 & nd & $\mathrm{IH}$ & $4 \mathrm{H}$ & $A$ & $A$ & $A B$ & 252 & $\mathrm{IH}$ \\
\hline I_0059 & $3 \mathrm{H}$ & $\mathrm{IH}$ & nd & $A$ & $A$ & B & I & nd \\
\hline I_0828 & $6 \mathrm{H}$ & $\mathrm{IH}$ & nd & A & B & A & I & nd \\
\hline I_0942 & nd & $4 \mathrm{H}$ & $\mathrm{IH}$ & B & B & B & $1 / 476$ & $4 \mathrm{H}$ \\
\hline I_0316 & $\mathrm{IH}$ & $7 \mathrm{H}$ & $7 \mathrm{H}$ & B & B & B & $1 / 488$ & $7 \mathrm{H}$ \\
\hline I_1092 & $5 \mathrm{H}$ & $\mathrm{IH}$ & $5 \mathrm{H}$ & B & B & B & $1 / 515$ & $5 \mathrm{H}$ \\
\hline $1 \_1100$ & nd & $2 \mathrm{H}$ & $\mathrm{IH}$ & B & B & B & $1 / 722$ & $2 \mathrm{H}$ \\
\hline
\end{tabular}

nd - not determined, a I H GenCall score/2H-7H GenCall score, bchromosome location as determined by comparing GenCall scores for IH and $2 \mathrm{H}$ $-7 \mathrm{H}$

has subsequently been explained as incorrect use of subclusters to represent SNP variation in the targeted marker position.

Based on the above two analyses of $1 \mathrm{H}$ and $2 \mathrm{H}-7 \mathrm{H}$ markers and selecting ratios of 5.0 for $1 \mathrm{H}$ and 0.2 for $2 \mathrm{H}$ $-7 \mathrm{H}$, we can conclude that only 20 out of 1050 previously mapped loci $(1.9 \%)$ failed to be allocated to one of these two marker sets.

\section{Associating markers with unknown map position to chromosome IH}

A total of 349 loci targeted by the OPA and yielding high quality Akcent data were not previously mapped. The GenCall score ratio cutoff values discussed above removed 10 loci from further consideration and partitioned the remaining 339 loci into two bins: the $1 \mathrm{H}$ bin contained 40 markers $(11.8 \%)$ and the $2 \mathrm{H}-7 \mathrm{H}$ bin contained 299 markers (88.2\%) (Figure 4c). These proportions are very near the expected proportion of slightly less than $1 / 7$ of the total barley genome contained in chromosome $1 \mathrm{H}$. We analyzed barley-rice synteny by BLASTX of all rice proteins against these 40 HarvEST:Barley unigenes mapped to $1 \mathrm{H}$ [see Additional file 1]. The rice chromosomes with highest number of best blast hits were chromosomes five and ten with 24 and 8 hits, respectively. Stein et al. [39] placed 93 markers on $1 \mathrm{H}$ and also found the highest degree of synteny to rice chromosome five followed by chromosome ten.

\section{Genotyping of isolated chromosomes to clarify the map location of ambiguous loci}

The consensus map used in [36] contained 1153 OPAbased loci, of which 27 markers mapped to 2 different chromosomes (a total of 54 ambiguous markers). Of these 54 markers, 14 were mapped to $1 \mathrm{H}$ in at least one mapping population and had a high quality genotype call using Akcent DNA. In order to solve the correct map position for these ambiguous loci we examined the GenCall ratios as discussed above (Table 2). The correct chromosome assignments for 12 of these 14 loci were readily apparent from the GenCall ratios. The remaining two loci encode a GTP binding protein and a chlorophyll A/B binding protein, both of which belong to large multigene families, with 58 and 40 members, respectively. The high GenCall scores for these loci both in $1 \mathrm{H}$ and $2 \mathrm{H}-7 \mathrm{H}$ fractions indicate that the SNP markers target two loci on different chromosomes.

To summarize, among the 1426 interrogated Akcent loci, 1381 were unambiguously allocated to $1 \mathrm{H}$ or $2 \mathrm{H}-7 \mathrm{H}$ using flow-sorted chromosome DNA [see Additional file 2].

\section{Conclusion}

The present study demonstrates a method to produce unbiased microgram quantities of DNA from a small number of flow-sorted plant chromosomes, suitable for high throughput genetic marker systems. This is a significant breakthrough as the preparation of chromosomes in microgram quantities DNA requires weeks of sorting [17]. Depending on chromosome size, the ten ng quantity, required for representative amplification translates to only about $10-20$ thousand chromosomes. With a sorting speed of 20 chromosomes/sec [2], the required number of chromosomes can be sorted in less than 30 minutes. 
Although the amplified DNA of flow-sorted chromosomes is not of high molecular weight, the size of the amplified fragments $(5-30 \mathrm{~kb})$ may suit various applications, including the construction of chromosome-specific short-insert DNA libraries and genotyping assays. Shortinsert chromosome-specific DNA libraries constructed after MDA facilitated development of molecular markers from particular genome regions [11].

The use of the novel approach presented here is not limited to barley as the chromosome sorting technology has been developed for 17 plant species, including tetraploid and hexaploid wheat, rye or several legume species [6]. In some species it is possible to sort single chromosome arms, which represent only a few percent of the whole genome $[8,35]$. The ability to dissect genomes to small fractions is especially attractive when dealing with complex plant genomes.

We have established that chromosome sorting coupled with DNA amplification and the Illumina GoldenGate assay provides a powerful approach towards parallel mapping of DNA sequences to particular chromosomes. In this work, we have mapped 162 SNP loci to chromosome $1 \mathrm{H}$, including 40 loci with hitherto unknown map position. As the position of markers on genetic maps often can be questioned, we expect that this approach can be used to clarify many ambiguities. In summary, the ability to rapidly produce micrograms of chromosome-specific DNA significantly broadens the range of applications of flow-sorted chromosomes and chromosome arms in plant genomics.

\section{Abbreviations}

BAC: Bacterial Artificial Chromosome; CV: coefficient of variation; DOP-PCR: degenerate oligonucleotide primed PCR; FISH: fluorescence in situ hybridization; MDA: multiple displacement amplification; PEP: primer extension preamplification; PRINS: primed in situ labeling; RFLP: restriction fragment length polymorphism; SNP: single nucleotide polymorphism.

\section{Authors' contributions}

HŠ and JB optimized the procedure for multiple displacement amplification of flow-sorted chromosomes. JTS and PC performed real-time PCR analysis of amplification products. JTS analyzed the genotyping data and developed the strategy for bin mapping. EH analyzed the amplification product by Southern hybridization. PS flow sorted the barley chromosomes. PRB and TJC examined and helped resolve map position ambiguities. JŠ made an intellectual contribution to the concept of the experiment. HŠ and JTS drafted the manuscript. JD and TJC conceived and supervised the project and prepared the final version of the manuscript.

\section{Additional material}

\section{Additional file 1}

Analysis of 40 HarvEST:Barley unigenes mapped to $1 \mathrm{H}$. XLS file with a table displaying results of analysis of barley-rice synteny based on BLASTX of all rice proteins against these 40 HarvEST:Barley unigenes mapped to $1 \mathrm{H}$.

Click here for file

[http://www.biomedcentral.com/content/supplementary/14712164-9-294-S1.xls]

\section{Additional file 2}

Scheme of the mapping experiment. PDF file with a chart displaying illustratively the process of mapping using flow-sorted chromosomes and the results obtained. In the first stage, 1050 loci with known map position were analyzed (a) to define selecting GenCall score ratios for bin mapping. These parameters were used to analyze 349 loci with unknown map position (b) and to clarify the map location of 14 ambiguous loci (c). Click here for file

[http://www.biomedcentral.com/content/supplementary/14712164-9-294-S2.pdf]

\section{Acknowledgements}

We thank our colleagues Bc. Romana Nováková and Bc. Jitka Weiserová, for excellent technical assistance. This work was supported by the Czech Science Foundation (grant 52 I/05/H0 I3), Ministry of Education, Youth and Sports of the Czech Republic (grants ME884 and LC06004) and National Science Foundation (DBI-0321756).

\section{References}

I. The Community Sequecing Program [http://www.jgi.doe.gov/ CSP/index.html]

2. Doležel J, Kubaláková M, Paux E, Bartoš J, Feuillet C: Chromosomebased genomics in cereals. Chromosome Res 2007, 15:5I-66.

3. Peterson DG: Reduced representation strategies and their application to plant genomes. In The Handbook of Plant Genome Mapping: Genetic and Physical Mapping Edited by: Meksem K, Kahl G. Weinheim: WILEY-VCH Verlag GmbH \& Co. KgaA; 2005:307-335.

4. Keller B, Feuillet C, Yahiaoui N: Map-based isolation of disease resistance genes from bread wheat: cloning in a supersize genome. Genet Res 2005, 85(2):93-100.

5. Bossolini E, Wicker T, Knobel P, Keller B: Comparison of orthologous loci from small grass genomes Brachypodium and rice: implications for wheat genomics and grass genome annotation. Plant Journal 2007, 49:704-717.

6. Doležel J, Kubaláková M, Bartoš J, Macas J: Flow cytogenetics and plant genome mapping. Chromosome Res 2004, I 2:77-91.

7. Vrána J, Kubaláková M, Šimková $H$, Kíhalíková J, Lysák MA, Doležel J: Flow-sorting of mitotic chromosomes in common wheat (Triticum aestivum L.). Genetics 2000, 156:2033-204I.

8. Kubaláková M, Vrána J, Жíhalíková J, Šimková H, Doležel J: Flow karyotyping and chromosome sorting in bread wheat (Triticum aestivum L.). Theor Appl Genet 2002, I04: I 362-1372.

9. Požárková $D$, Kobližková A, Román B, Torres AM, Lucretti S, Lysák MA, Doležel J, Macas J: Development and characterization of microsatellite markers from chromosome I-specific DNA libraries of Vicia faba. Biol Plant 2002, 45:337-345.

10. Román B, Satovic Z, Požárková D, Macas J, Doležel J, Cubero Jl, Torres AM: Development of a composite map in Vicia faba, breeding applications and future prospects. Theor Appl Genet 2004, 108: 1079-1088.

II. Kofler R, Bartoš J, Gong L, Stift G, Suchánková P, Šimková H, Berenyi M, Burg K, Doležel J, Lelley T: Development of microsatellite markers specific for the short arm of rye (Secale cereale $L$. chromosome I. in press. 
12. Vláèilová K, Ohri D, Vrána J, Kíhalíková J, Kubaláková M, Kahl G, Doležel J: Development of flow cytogenetics and physica genome mapping in chickpea (Cicer arietinum L.). Chromosomes Res 2002, 10:695-706.

13. Neumann P, Požárková D, Vrána J, Doležel J, Macas J: Chromosome sorting and PCR-based physical mapping in pea (Pisum sativum L.). Chromosome Res 2002, 10:63-7I.

14. Kubaláková M, Vrána J, Жíhalíková J, Lysák MA, Doležel J: Localisation of DNA sequences on plant chromosomes using PRINS and C-PRINS. Methods Cell Sci 200I, 23:7I-82.

15. Kubaláková $M$, Kovářová $P$, Suchánková $P$, Kíhalíková J, Bartoš J, Lucretti S, Watanabe N, Kianian SF, Doležel J: Chromosome sorting in tetraploid wheat and its potential for genome analysis. Genetics 2005, I 70:823-829.

16. Valárik $M$, Bartoš J, Kovářová $P$, Kubaláková $M$, de Jong $H$, Doležel J: High-resolution FISH on super-stretched flow-sorted plant chromosomes. Plant Journal 2004, 37:940-950.

17. Šafár J, Bartoš J, Janda J, Bellec A, Kubaláková M, Valárik M, Pateyron $S$, Weiserová J, Tušková R, Kíhalíková J, Vrána J, Šimková H, FaivreRampant P, Sourdille P, Caboche M, Bernard M, Doležel J, Chalhoub $B$ : Dissecting large and complex genomes: flow sorting and BAC cloning of individual chromosomes from bread wheat. Plant Journal 2004, 39:960-968.

18. Janda J, Bartoš J, Šafář J, Kubaláková M, Valárik M, Жíhalíková J, Šimková H, Caboche M, Sourdille P, Bernard M, Chalhoub B, Doležel J: Construction of a subgenomic BAC library specific for chromosomes ID, 4D and 6D of hexaploid wheat. Theor Appl Genet 2004, 109:1337-1345.

19. Janda J, Šafář J, Kubaláková $M$, Bartoš J, Kovářová $P$, Suchánková $P$, Pateyron S, Kíhalíková J, Sourdille P, Simková H, Fairaivre-Rampant P, Hřibová E, Bernard M, Lukaszewski A, Doležel J, Chalhoub B: Advanced resources for plant genomics: BAC library specific for the short arm of wheat chromosome IB. Plant Journal 2006, 47:977-986.

20. Paux E, Sourdille P, Salse J, Saintenac C, Choulet F, Leroy F, Korol A, Spielmeyer W, Appels R, Doležel J, Bernard M, Feuillet C: Physical mapping in a giant genome: A chromosome landing-ready physical map of chromosome 3B of hexaploid wheat. In Abstracts of the International Conference Plant and Animal Genome XVI: 12-I6 January 2008; San Diego, CA Sherago International, Inc; 2008:65.

21. McNeil MD, Kota R, Paux E, Dunn D, McLean R, Feuillet C, Li D, Kong X, Lagudah E, Zhang JC, Jia JZ, Spielmeyer W, Bellgard M, Appels R: BAC-derived markers for assaying the stem rust resistence gene, Sr2, in wheat breeding programs. Mol Breeding 2008.

22. Telenius $H$, Carter NP, Bebb CE, Nordenskjold M, Ponder BA, Tunnacliffe A: Degenerate oligonucleotide-primed PCR: general amplification of target DNA by a single degenerate primer. Genomics 1992, 13:718-725.

23. Zhang L, Cui X, Schmitt K, Hubert R, Navidi W, Arnheim N: Whole genome amplification from a single cell: implications for genetic analysis. Proc Natl Acad Sci USA 1992, 89:5847-585I.

24. Dean FB, Hosono S, Fang L, Wu X, Faruqi AF, Bray-Ward P, Sun Z, Zong Q, Du Y, Du J, Driscoll M, Song W, Kingsmore SF, Egholm M, Lasken RS: Comprehensive human genome amplification using multiple displacement amplification. Proc Natl Acad Sci USA 2002, 99:526I-5266.

25. Pinard R, de Winter A, Sarkis GJ, Gerstein MB, Tartaro KR, Plant RN, Egholm M, Rothberg JM, Leamon JH: Assessment of whole genome amplification-induced bias through high-throughput, massively parallel whole genome sequencing. BMC Genomics 2006, 7:216.

26. Dean FB, Nelson JR, Giesler TL, Lasken RS: Rapid amplification of plasmid and phage DNA using Phi 29 DNA polymerase and multiply-primed rolling circle amplification. Genome Res 200I, I I:1095-1099.

27. Lage JM, Leamon JH, Pejovic T, Hamann S, Lacey M, Dillon D, Segraves $R$, Vossbrinck B, Gonzalez A, Pinkel D, Albertson DG, Costa J, Lizardi PM: Whole genome analysis of genetic alterations in small DNA samples using hyperbranched strand displacement amplification and array-CGH. Genome Res 2003, 13:294-307.

28. Hosono S, Faruqi AF, Dean FB, Du Y, Sun Z, Wu X, Du J, Kingsmore SF, Egholm M, Lasken RS: Unbiased whole-genome amplification directly from clinical samples. Genome Res 2003, I 3:954-964
29. Barker DL, Hansen MS, Faruqi AF, Giannola D, Irsula OR, Lasken RS, Latterich M, Makarov V, Oliphant A, Pinter JH, Shen R, Sleptsova I, Ziehler W, Lai E: Two methods of whole genome amplification enable accurate genotyping across a 2320-SNP linkage panel. Genome Res 2004, I 2:901-90I.

30. Paez JG, Lin M, Beroukhim R, Lee JC, Zhao X, Richter DJ, Gabriel S, Herman P, Sasaki H, Altshuler D, Li C, Meyerson M, Sellers WR: Genome coverage and sequence fidelity of phi29 polymerase-based multiple strand displacement whole genome amplification. Nucleic Acids Res 2004, 32:e7I.

3I. Pask R, Rance HE, Barratt BJ, Nutland S, Smyth DJ, Sebastian M, Twells RC], Smith A, Lam AC, Smink LJ, Walker NM, Todd JA: Investigating the utility of combining Phi29 whole genome amplification and highly multiplexed single nucleotide polymorphism BeadArray genotyping. BMC Biotechnol 2004, 4:15.

32. Park JW, Beaty TH, Boyce P, Scott AF, Mclntosh I: Comparing whole-genome amplification methods and sources of biological samples for single-nucleotide polymorphism genotyping. Clin Chem 2005, 5 I: I 520-I523.

33. Lysák MA, Жíhalíková J, Kubaláková M, Šimková H, Künzel G, Doležel J: Flow karyotyping and sorting of mitotic chromosomes of barley (Hordeum vulgare L.). Chromosome Res 1999, 7:43 I-444.

34. Doležel J, Binarová P, Lucretti S: Analysis of nuclear DNA content in plant cells by flow cytometry. Biol Plant 1989, 31:113-120.

35. Suchánková $P$, Kubaláková $M$, Kovářová $P$, Bartoš J, Kíhalíková J, Molnár-Láng $M$, Endo TR, Doležel J: Dissection of the nuclear genome of barley by chromosome flow sorting. Theor Appl Genet 2006, I 1 3:651-659.

36. Rostoks N, Ramsay L, Mackenzie K, Cardle L, Bhat PR, Roose ML Svensson JT, Stein N, Varshney RK, Marshall DF, Graner A, Close TJ, Waugh R: Recent history of artificial outcrossing facilitates whole-genome association mapping in elite inbred crop varieties. Proc Natl Acad Sci USA 2006, 103: I8656- I866I.

37. Rook MS, Delach SM, Deyneko G, Worlock A, Wolfe JL: Whole genome amplification of DNA from laser capturemicrodissected tissue for high-throughput single nukleotide polymorphism and short tandem repeat genotyping. Am J Pathol 2004, 164:23-33.

38. Bergen AW, Qi Y, Haque KA, Welch RA, Chanock SJ: Effects of DNA mass on multiple displacement whole genome amplification and genotyping performance. BMC Biotechnol 2005, 5:24.

39. Stein N, Prasad M, Scholz U, Thiel T, Zhang H, Wolf M, Kota R, Varshney RK, Perovic D, Grosse I, Graner A: A I,000-loci transcript map of the barley genome: new anchoring points for integrative grass genomics. Theor Appl Genet 2007, I I 4:823-839.

Publish with Bio Med Central and every scientist can read your work free of charge

"BioMed Central will be the most significant development for disseminating the results of biomedical research in our lifetime. "

Sir Paul Nurse, Cancer Research UK

Your research papers will be:

- available free of charge to the entire biomedical community

- peer reviewed and published immediately upon acceptance

- cited in PubMed and archived on PubMed Central

- yours - you keep the copyright 